\title{
INFLUENCE OF MOTHER'S KNOWLEDGE ABOUT TYPE OF WEANING FOOD ON THE NUTRITIONAL STATUS OF 6-24 MONTHS CHILDREN IN POSYANDU GODAN VILLAGE, TAWANGHARJO
}

\author{
By; \\ Ratna Sri Rahayu ${ }^{1}$, Sutrisno $^{2}$, Sulistiyarini ${ }^{3}$ \\ 1) Student of STIKES An Nur Purwodadi, Email ratnarahayu647@gmail.com \\ 2) Lecturer of STIKES An Nur Purwodadi; Email; glorious354@ gmail.com \\ 3) Lecturer of STIKES An Nur Purwodadi, Email; sulistiyarini0@ gmail.com
}

\begin{abstract}
Background; Nutrition plays an important role in the growthof the child. According to the World Health Organization (2016) 6\% or 40,6 million are overfed and 7,7\% or 52 million malnourished. Knowledge is one of the internal factors that affect the nutritional status of children (Notoatmodjo, 2007). According to Mulyana (2011), 29 (40,3\%) of respondents who have less knowledge have malnourished children. Based on WHO (2007) in Syatriani (2010), $54 \%$ of 11 million children under five around the world die from malnutrition and $46 \%$ died due to concomitant diseases such as respiratory infections, diarrhea, malaria and measles.

Purpose - To determine the effect of mother's knowledge about the type of weaning foods on the nutritional status of 6-24 months children in Posyandu Godan Village Sub-District of Tawangharjo.

Method; Design research was analytic survey with case control approach with Chi Square test. The population were 132 respondents. Sample collectingused non-probability sampling Quota method. Sample case group were 30 respondents and control groups were 30 respondents.

Result; Mothers with good knowledgewho have children with bad nutritional status are 9 (15\%) respondents while mothers with bad knowledge who havechildren with good nutritional status are 21 (35\%) respondents. Mothers with good knowledge who have children with good nutritional status are 20 (33,3\%) respondents while the mothers with bad knowledge who have children with good nutritional status are $10(16,7 \%)$ respondents. $\rho$ value = 0,010 and 4,667 Odds Ratio value. It means that there is influence of mother's knowledge about the type of weaning foods on the nutritional status of 6-24 month children in the Godan Village Tawangharjosub-District.

Conclusion; There isinfluence of mother's knowledge about the type of weaning foods on the nutritional status of 6-24 months children in Posyandu Godan Village Sub-District of Tawangharjo.
\end{abstract}

Keywords : Nutritional Status, Weaning Food, Knowledge Level 


\section{PENDAHULUAN}

Pengetahuan merupakan hasil dari tahu dan ini terjadi setelah orang melakukan penginderaan terhadap suatu objek tertentu. Pengetahuan merupakan salah satu faktor internal yang mempengaruhi status gizi anak ${ }^{1}$. Gizi sangat berperan dalam tumbuh kembang anak. Tujuan pemberian gizi yang baik adalah mencapai tumbuh kembang anak yang adekuat. Pada bayi dan anak, kekurangan gizi akan menimbulkan gangguan pertumbuhan dan perkembangan yang apabila tidak diatasi secara dini akan berlanjut hingga dewasa ${ }^{2}$.

Data status gizi anak usia dibawah lima tahun menurut World Health Organization (2016) sebesar 6\% atau 40,6 juta mengalami gizi lebih dan $7,7 \%$ atau 52 juta mengalami gizi buruk ${ }^{3}$.

Berdasarkan hasil Riset Kesehatan Dasar secara nasional, prevalensi status gizi balita yaitu sebesar 5,3\% balita sangat kurus dan balita kurus sebesar 6,8\% ${ }^{4}$. Hasil survei status gizi pada balita usia 0-23 bulan oleh Kementerian Kesehatan Republik Indonesia, ditemukan balita sangat kurus di wilayah Maluku sebesar 9,1\%, Papua sebesar 6,6\% dan Nusa Tenggara Timur sebesar 6,2\%. Sedangkan persentase balita kurus di wilayah Maluku sebesar 12,4\%, Papua Barat sebesar 11,4\% dan Nusa Tenggara Timur 11,3\%. Sedangkan persentase balita gemuk di wilayah Papua sebesar 6,9\%, Sulawesi Utara 6,5\% dan Nusa Tenggara Timur serta Bali sebesar 6,2\% ${ }^{5}$.

Berdasarkan data dari Kementerian Kesehatan Jawa Tengah pada tahun 2015, jumlah kasus balita gizi buruk sebanyak 922 kasus dimana kasus balita gizi buruk terbanyak adalah di Brebes yaitu 82 kasus, diikuti Cilacap 76 kasus, dan Tegal 57 kasus ${ }^{6}$. Sedangkan hasil survei Dinkes Grobogan (2016) terdapat data status gizi buruk sebanyak 34 kasus di wilayah kerja Puskesmas Gabus 1, 32 kasus di wilayah kerja Puskesmas Tawangharjo, 31 kasus di wilayah kerja Puskesmas Brati 1, 23 kasus di wilayah kerja Puskesmas Geyer 2 dan 21 kasus di wilayah kerja Puskesmas Godong $1^{7}$.

Menurut data dari WHO, tercatat 54\% dari 11 juta balita diseluruh dunia meninggal akibat gizi buruk dan $46 \%$ meninggal diakibatkan oleh penyakit penyerta seperti ISPA, diare, malaria dan campak $^{8}$.

Berdasarkan penelitian yang dilakukan oleh Sudarsih (2014) menunjukkan bahwa ibu yang memiliki tingkat pengetahuan tidak baik sebanyak $26(63 \%)$ dari 41 responden dan anak dengan status gizi tidak baik sebanyak 22 $(53,6 \%)$ dari 41 responden ${ }^{9}$. Penelitian yang dilakukan oleh Burhani et al., (2015) menunjukkan bahwa ibu yang memiliki 
tingkat pengetahuan tidak baik sebanyak $11(52,3 \%)$ dari 21 responden ${ }^{10}$.

Berdasarkan data yang diperoleh di desa Godan pada tanggal 26 Februari 2018 didapatkan hasil 132 anak usia 6-24 bulan. Berdasarkan wawancara dari $10 \mathrm{ibu}$ yang memiliki anak usia 6-24 bulan diperoleh anak dengan status gizi baik 4 (40\%) orang dengan tingkat pengetahuan ibu baik sebanyak 3 orang dan tingkat pengetahuan ibu tidak baik 1 orang sedangkan anak dengan status gizi tidak baik sebanyak 6 (60\%) orang dengan tingkat pengetahuan ibu baik sebanyak 2 orang dan tingkat pengetahuan ibu tidak baik sebanyak 4 orang.

Dari hasil studi pendahuluan yang telah dilakukan peneliti tertarik untuk melakukan penelitian tentang pengaruh tingkat pengetahuan ibu tentang jenis MPASI terhadap status gizi anak usia 6-24 bulan di Desa Godan Kecamatan Tawangharjo.

\section{METODE}

Jenis penelitian ini merupakan penelitian kuantitatif dengan desain penelitian survey analitik dan menggunakan pendekatan Case Control yang bersifat retrospektif dengan kata lain efek (penyakit atau status kesehatan) yang diidentifikasi pada saat ini kemudian faktor risiko diidentifikasi adanya atau terjadi pada waktu yang lalu ${ }^{11}$.
Populasi pada penelitian ini adalah semua ibu yang mempunyai anak usia 6-24 bulan di Posyandu Balita desa Godan Tawangharjo sejumlah 132 responden. Sampel dalam penelitian ini berdasarkan kriteria inklusi adalah sebanyak 30 responden dan sebanyak 30 responden lainnya sebagai kelompok kontrol.

Teknik sampling yang digunakan dalam penelitian ini adalah nonprobability sampling dengan metode Quota Sampling yaitu pengambilan anggota sample secara quotum atau jatah ${ }^{11}$.

Variabel independen dalam penelitian ini adalah tingkat pengetahuan ibu dan variabel dependen dalam penelitian ini adalah status gizi anak. Metode pengumpulan data yang digunakan dalam penelitian ini adalah kuesioner. Uji statistik yang digunakan dalam penelitian ini adalah Chi-Square.

\section{HASIL}

Tabel 1; Distribusi Umur Ibu dengan Anak Status Gizi Tidak Baik

\begin{tabular}{lcc}
\hline \multicolumn{1}{c}{ Umur (Tahun) } & $\mathbf{f ( \% )}$ & Mean \\
\hline$\leq 20$ & $2(6,6 \%)$ & \\
$21-30$ & $20(66,7 \%$ & \multirow{2}{*}{27,37} \\
$>30$ & $8(26,6 \%)$ & \\
\cline { 1 - 2 } Total & $\mathbf{3 0 ( 1 0 0 \% )}$ & \\
\hline
\end{tabular}

Tabel 2; Distribusi Umur Ibu dengan Anak Status Gizi Baik 


\begin{tabular}{lcc}
\hline \multicolumn{1}{c}{ Umur (Tahun) } & $\mathbf{f ( \% )}$ & Mean \\
\hline$\leq 20$ & $5(16,6 \%)$ & \\
$21-30$ & $20(66,7 \%)$ & \multirow{2}{*}{26,50} \\
$>30$ & $5(16,6 \%)$ & \\
\cline { 1 - 2 } Total & $\mathbf{3 0 ( 1 0 0 \% )}$ & \\
\hline
\end{tabular}

Tabel 3; Distribusi Pendidikan Ibu dengan Anak Status Gizi Tidak Baik

\begin{tabular}{|c|c|}
\hline Pendidikan & Frekuensi (\%) \\
\hline SMP & $16(53,3 \%)$ \\
\hline SMA & $14(46,7 \%)$ \\
\hline Total & $30(100 \%)$ \\
\hline
\end{tabular}

Tabel 4; Distribusi Pendidikan Ibu dengan Anak Status Gizi Tidak Baik

\begin{tabular}{|c|c|}
\hline Pendidikan & Frekuensi (\%) \\
\hline SMP & $19(63,3 \%)$ \\
\hline SMA & $11(36,7 \%)$ \\
\hline Total & $30(100 \%)$ \\
\hline
\end{tabular}

Tabel 5; Distribusi Pekerjaan Ibu dengan

Anak Status Gizi Tidak Baik

\begin{tabular}{ll}
\hline \multicolumn{1}{c}{ Pekerjaan } & Frekuensi (\%) \\
\hline Ibu Rumah Tangga & $23(76,6 \%)$ \\
Petani & $5(16,6 \%)$ \\
Wiraswasta & $2(6,7 \%)$ \\
\hline \multicolumn{1}{c}{ Total } & $\mathbf{3 0}(\mathbf{1 0 0 \% )}$ \\
\hline
\end{tabular}

Tabel 6; Distribusi Pekerjaan Ibu dengan Anak Status Gizi Baik

\begin{tabular}{|c|c|}
\hline Pekerjaan & $\mathbf{f}(\%)$ \\
\hline Ibu Rumah Tangga & $20(6,7 \%)$ \\
\hline Petani & $7(23,3 \%)$ \\
\hline Wiraswasta & $3(10,0 \%)$ \\
\hline Total & $30(100 \%)$ \\
\hline
\end{tabular}

\section{Analisa Univariat}

Tabel 7 Status Gizi

\begin{tabular}{ccc}
\hline Valid & $(\mathbf{n})$ & $\mathbf{( \% )}$ \\
\hline Status Gizi Baik & 30 & 50 \\
Status Gizi Tidak Baik & 30 & 50 \\
\hline Total & $\mathbf{6 0}$ & $\mathbf{1 0 0}$ \\
\hline
\end{tabular}

Tabel 8; Tingkat Pengetahuan Ibu

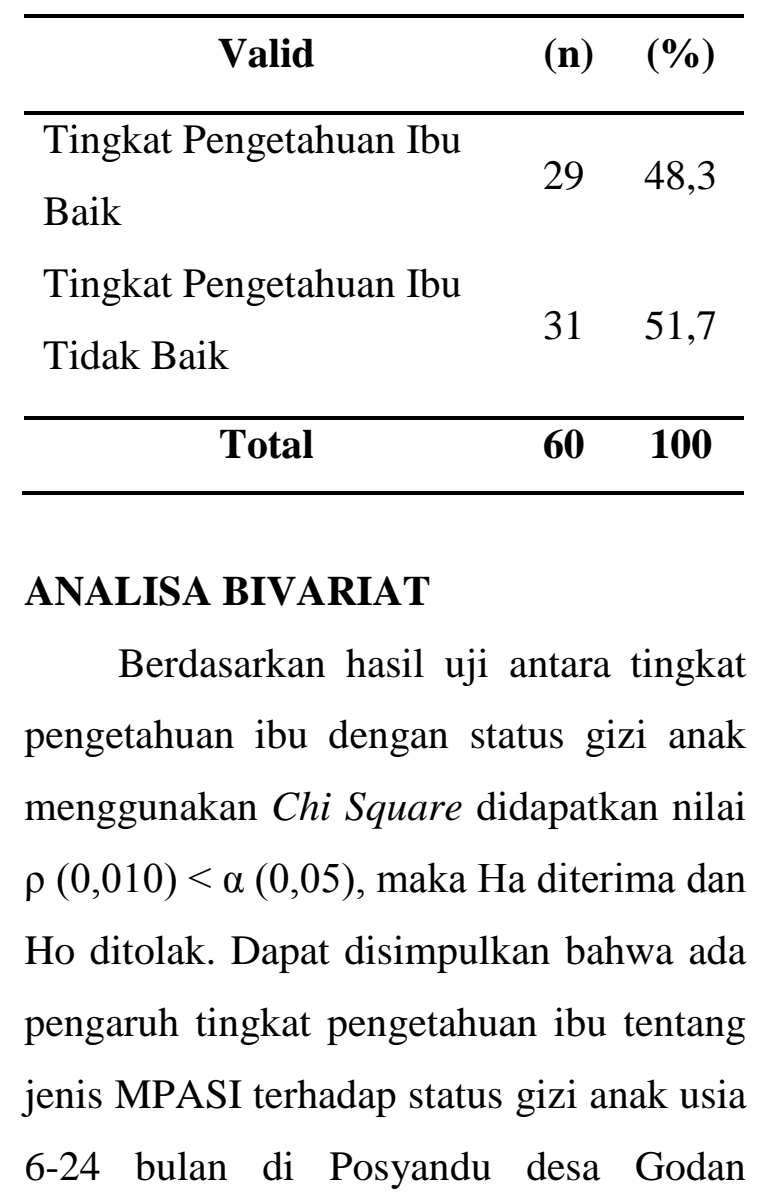


Kecamatan Tawangharjo. Hasil Odds Ratio sebesar 4,667 artinya responden dengan tingkat pengetahuan tidak baik mempunyai kemungkinan 4,667 kali untuk mempunyai anak dengan status gizi tidak baik.

\section{PEMBAHASAN}

Berdasarkan hasil penelitian diketahui bahwa tingkat pengetahuan ibu baik dengan status gizi anak tidak baik sebanyak $9(15 \%)$ responden sedangkan tingkat pengetahuan ibu tidak baik dengan status gizi anak tidak baik sebanyak 21 $(35 \%)$ responden. Tingkat pengetahuan ibu baik dengan status gizi anak baik sebanyak $20(33,3 \%)$ responden sedangkan tingkat pengetahuan ibu tidak baik dengan status gizi anak baik sebanyak $10 \quad(16,7 \%)$ responden.

Berdasarkan hasil uji komparatif $C h i$ Square didapatkan hasil uji antara tingkat pengetahuan ibu dengan status gizi anak diketahui nilai $\rho$ value $(0,010)<\alpha(0,05)$. Dari hasil tersebut dapat ditarik kesimpulan bahwa terdapat pengaruh tingkat pengetahuan ibu tentang jenis MPASI terhadap status gizi anak usia 6-24 bulan di posyandu desa Godan Kecamatan Tawangharjo. Hasil OR (Odds Ratio) sebesar 4,667 artinya responden dengan tingkat pengetahuan tidak baik 4,667 kali mempunyai kesempatan memiliki anak dengan status gizi tidak baik.
Responden yang memiliki tingkat pengetahuan rendah atau tidak baik berisiko memiliki anak dengan status gizi tidak baik atau kurang karena responden kurang memahami tentang nutrisi atau jenis MPASI yang tepat untuk pertumbuhan balita.

Kurangnya wawasan tersebut juga dikarenakan responden merupakan ibu rumah tangga sehingga pengalaman yang terbentuk hanya didapatkan dari lingkungan sekitar rumah dan posyandu.

Status tidak bekerja atau sebagai ibu rumah tangga, ibu sebenarnya memiliki waktu luang jika bisa memanfaatkan dengan baik sehingga ibu bisa mencari informasi tentang nutrisi anak yang tepat. Selain itu, semakin tinggi tingkat pendidikan maka semakin mudah dalam menerima informasi sehingga pengetahuan yang dimiliki semakin banyak.

Kurangnya informasi tentang kesehatan anak terlebih tentang nutrisi anak membuat ibu tidak bisa memilih nutrisi yang tepat untuk anaknya. Rendahnya tingkat pengetahuan ibu dapat menyebabkan rendahnya wawasan, pengalaman, motivasi, cara berpikir atau keterampilan dalam berbagai aspek dimasyarakat pada umumnya dan kesehatan anak pada khususnya.

Apabila tingkat pengetahuan ibu kurang atau tidak baik maka pola asuh atau informasi gizi/kesehatan anak menjadi 
kurang baik sehingga akan berpengaruh terhadap status gizi atau status kesehatan anak. Jika tingkat pengetahuan ibu tentang jenis MPASI baik, maka akan mengubah perilaku atau sikap ibu dalam memberikan jenis MPASI yang sesuai dengan kebutuhan nutrisi pada usia tertentu sehingga kebutuhan nutrisi anak terpenuhi.

Menurut Sudarsih (2014), pengetahuan responden yang kurang menunjukkan responden kurang mampu untuk mengingat kembali informasi yang pernah diperolehnya mengenai gizi balita. Kurangnya pengetahuan tersebut menyebabkan perilakunya dalam mengasuh makan balita juga kurang baik sehingga status gizi balita juga kurang baik $^{9}$.

Menurut Titisari, Kundarti, \& Susanti, (2010) terjadinya gizi kurang pada balita bukan berarti ibu tidak memberikan banyak makanan untuk balitanya. Namun dengan kurangnya pengetahuan ibu dalam memilih, mengolah dan menghidangkan makanan untuk balita menjadi kurang benar sehingga zat gizi yang terkandung dalam makanan menjadi berkurang ${ }^{12}$.

Menurut Marmi (2013) status gizi dapat dipengaruhi oleh faktor tidak langsung seperti pendapatan, pendidikan, pekerjaan, budaya dan pengetahuan. Semakin banyak pendapatan suatu keluarga maka daya beli terhadap suatu barang juga akan meningkat. Taraf ekonomi yang rendah juga merupakan indikator masalah gizi. Tingkat pendidikan orang tua atau ibu yang baik akan merubah pengetahuan dan perilaku tentang gizi balita sehingga ibu dapat memenuhi kebutuhan nutrisi balita. Pekerjaan merupakan suatu aktifitas yang dilakukan individu untuk menghasilkan uang sehingga dapat memenuhi kebutuhan hidup seperti makan, minum, pakaian dan lain-lain.

Tingkat pengetahuan yang baik tentang jenis MPASI maka kebutuhan nutrisi balita akan terpenuhi. Sedangkan faktor langsung seperti umurn kondisi fisik dan infeksi. Umur akan mempengaruhi kemampuan ibu dalam memberikan nutrisi pada balita. Infeksi suatu penyakit akan menjadikan kondisi fisik melemah dan tubuh akan sulit menerima nutrisi sehingga status gizi balita akan terganggu ${ }^{13}$.

Hasil penelitian ini diperkuat oleh penelitian yang dilakukan oleh Sudarsih (2014) yang menunjukkan bahwa ibu yang memiliki tingkat pengetahuan tidak baik sebanyak 26 (63\%) dari 41 responden dan anak dengan status gizi tidak baik sebanyak $22(53,6 \%)$ dari 41 responden ${ }^{9}$.

Penelitian yang dilakukan oleh Burhani et al., (2015) tentang Hubungan Tingkat Pengetahuan Ibu dan Tingkat Ekonomi Keluarga Nelayan dengan Status Gizi Balita di Kelurahan Air Tawar Barat Kota Padang menunjukkan bahwa ibu 
yang memiliki tingkat pengetahuan tidak baik sebanyak $11(52,3 \%)$ dari 21 responden ${ }^{10}$. Sedangkan penelitian yang dilakukan oleh Rahmiwati (2015) tentang Hubungan Pengetahuan Ibu Dan Status Gizi pada Anak Usia Bawah Dua Tahun yang Diberi Susu Formula Di Daerah Tanjung Raja, Kabupaten Ogan Ilir 2015 menunjukkan bahwa ibu dengan tingkat pengetahuan tidak baik sebanyak 68 $(72,3 \%)$ dan anak dengan status tidak baik sebanyak 12 responden ${ }^{14}$.

\section{KESIMPULAN}

Berdasarkan hasil penelitian yang telah dilakukan, maka dapat diambil kesimpulan bahwa ada pengaruh tingkat pengetahuan ibu tentang jenis MPASI. Ibu dengan tingkat pengetahuan rendah berisiko memiliki anak dengan status gizi tidak baik.

\section{DAFTAR PUSTAKA}

Notoatmodjo. (2007). Metodologi Penelitian Kesehatan.

Lestari. (2012). Hubungan pemberian Makanan Pendamping Asi (MP-ASI) dengan Status Gizi Anak Usia 1-3 Tahun di Kota Padang Tahun 2012.

WHO. (2016). Level and Trends in Child Malnutrition.

Riskesdas. (2013). RISET KESEHATAN DASAR. Jakarta.
Kemenkes RI. (2011). Standar Antropometri Penilaian Status Gizi Anak. Jakarta.

Kemenkes RI. (2015). Buku Ajar Kesehatan Ibu dan Anak. Jakarta: Bakti Husada.

Dinkes Grobogan. (2016). Dinas Kesehatan Kabupaten Grobogan. Grobogan.

WHO. (2007). A Safer Future.

Sudarsih, S. (2014). Hubungan Pengetahuan Dan Sikap Ibu Tentang Status Gizi Balita Di Desa Jabon Kecamatan Mojoanyar Kabupaten Mojokerjo, 6(1), 57-82.

Burhani, P. A., Oenzil, F., \& Revilla, G. (2015). Hubungan Tingkat Pengetahuan Ibu dan Tingkat Ekonomi Keluarga Nelayan dengan Status Gizi Balita di Kelurahan Air Tawar Barat Kota Padang, 5(3), 515521.

Notoatmodjo, S. (2010). Metodologi Penelitian Kesehatan. Jakarta: Rineka Cipta.

Titisari, I., Kundarti, F. I., \& Susanti, M. (2010). Hubungan Pengetahuan Ibu Tentang Gizi Dengan Status Gizi Balita Usia 1-5 Tahun Di Desa Kedawung Wilayah Kerja Puskesmas Ngadi, 20-28.

Marmi. (2013). Gizi Dalam Kesehatan Reproduksi. Pustaka Pelajar.

Rahmiwati, A. (2015). Hubungan Pengetahuan Ibu Dan Status Gizi pada Anak Usia Bawah Dua Tahun yang Diberi Susu Formula Di Daerah Tanjung Raja, Kabupaten Ogan Ilir 2015. 